\title{
Recent Progress in Carbon Fiber Reinforced Polymers Recycling: A Review of Recycling Methods and Reuse of Carbon Fibers
}

\author{
José Antonio Butenegro $^{1, *(\mathbb{D})}$, Mohsen Bahrami ${ }^{1} \mathbb{D}$, Juana Abenojar ${ }^{1,2}$ and Miguel Ángel Martínez ${ }^{1} \mathbb{D}$ \\ 1 Materials Science and Engineering and Chemical Engineering Department, IAAB, University Carlos III \\ Madrid, 28911 Leganés, Spain; mbahrami@ing.uc3m.es (M.B.); abenojar@ing.uc3m.es (J.A.); \\ mamc@ing.uc3m.es (M.Á.M.) \\ 2 Mechanical Engineering Department, Universidad Pontificia Comillas, Alberto Aguilera 25, \\ 28015 Madrid, Spain \\ * Correspondence: jbuteneg@ing.uc3m.es; Tel.: +34-655390804
}

Citation: Butenegro, J.A.; Bahrami, M.; Abenojar, J.; Martínez, M.Á. Recent Progress in Carbon Fiber Reinforced Polymers Recycling: A Review of Recycling Methods and Reuse of Carbon Fibers. Materials 2021, 14, 6401. https://doi.org/ $10.3390 /$ ma14216401

Academic Editor: Gabriele Milani

Received: 6 October 2021

Accepted: 23 October 2021

Published: 25 October 2021

Publisher's Note: MDPI stays neutral with regard to jurisdictional claims in published maps and institutional affiliations.

Copyright: (C) 2021 by the authors. Licensee MDPI, Basel, Switzerland. This article is an open access article distributed under the terms and conditions of the Creative Commons Attribution (CC BY) license (https:/ / creativecommons.org/licenses/by/ $4.0 /)$.

\begin{abstract}
The rapid increase in the application of carbon fiber reinforced polymer (CFRP) composite materials represents a challenge to waste recycling. The circular economy approach coupled with the possibility of recovering carbon fibers from CFRP waste with similar properties to virgin carbon fibers at a much lower cost and with lower energy consumption motivate the study of CFRP recycling. Mechanical recycling methods allow the obtention of chopped composite materials, while both thermal and chemical recycling methods aim towards recovering carbon fibers. This review examines the three main recycling methods, their processes, and particularities, as well as the reuse of recycled carbon fibers in the manufacture of new composite materials.
\end{abstract}

Keywords: polymer matrix composites; carbon fibers; recycling methods; circular economy

\section{Introduction}

The demand for carbon fiber reinforced polymer (CFRP) composite materials is increasing rapidly, powered by a wide variety of industries such as general transport, including aerospace, automotive and sea vehicles; defense; wind turbines; construction; marine; sports; leisure; and storage tanks [1-8]. The growing demand for CFRP composites (four times the annual growth rate of global gross domestic product (GDP) per capita over the past decade [9-11]) in industry as a high-performance, light-weight materials is a result of their high specific strength, high specific stiffness, high fatigue resistance, good corrosion resistance, high durability, and low density. This last property is essential for aerospace and automotive industries, which strive to achieve energy efficiency while reducing the dependence on oil [12].

Fiber reinforced polymer (FRP) composite materials consist of a polymeric matrix and reinforcement fibers, making CFRP a subgroup of FRP. The matrix is usually a thermoset polymer, due to its better mechanical properties and better fiber-matrix adhesion, compared to thermoplastic polymers, but thermoplastics can be used as matrices as well. The most common polymers used as matrices are polyester, acrylic and epoxy resins [13,14]. Fibers enhance the mechanical properties of the composite material. Glass fibers have typically been the most economical choice among fibers. However, carbon fibers are employed for high-value, high-performance applications, where high specific properties are critical. Polyacrylonitrile (PAN) carbon fiber is the predominant type of fiber due to its relative ease of production and ability to maintain excellent mechanical properties. Other fibers, such as aramid, boron or basalt, are also being used for very specific applications, but their volumes are irrelevant compared to glass fibers or carbon fibers reinforced polymers [15-18]. Natural fibers are of interest since they can be extracted from renewable sources of animals, vegetable plants, and also minerals [19]. 
However, the most important disadvantage of FRPs is the difficulty of recycling them. Landfilling and incineration have been the predominant recycling methods for a long time. However, these are not sustainable approaches since they are unable to solve the issues related to waste accumulation (landfilling) or require intensive energy consumption (incineration) [20]. FRP recycling is not carried out for economic reasons, as the recycled fibers obtained are short (therefore losing the added value of long fibers) and more expensive than virgin fibers. Thus, the motivation for recycling is not to reduce raw material costs but to cope with the high volume of FRP waste that is expected in the upcoming years, when wind energy elements and aircrafts reach their end-of-life [21]. An example of the environmental impact caused by the accumulation of FRP at end-of-life is shown in Figure 1.

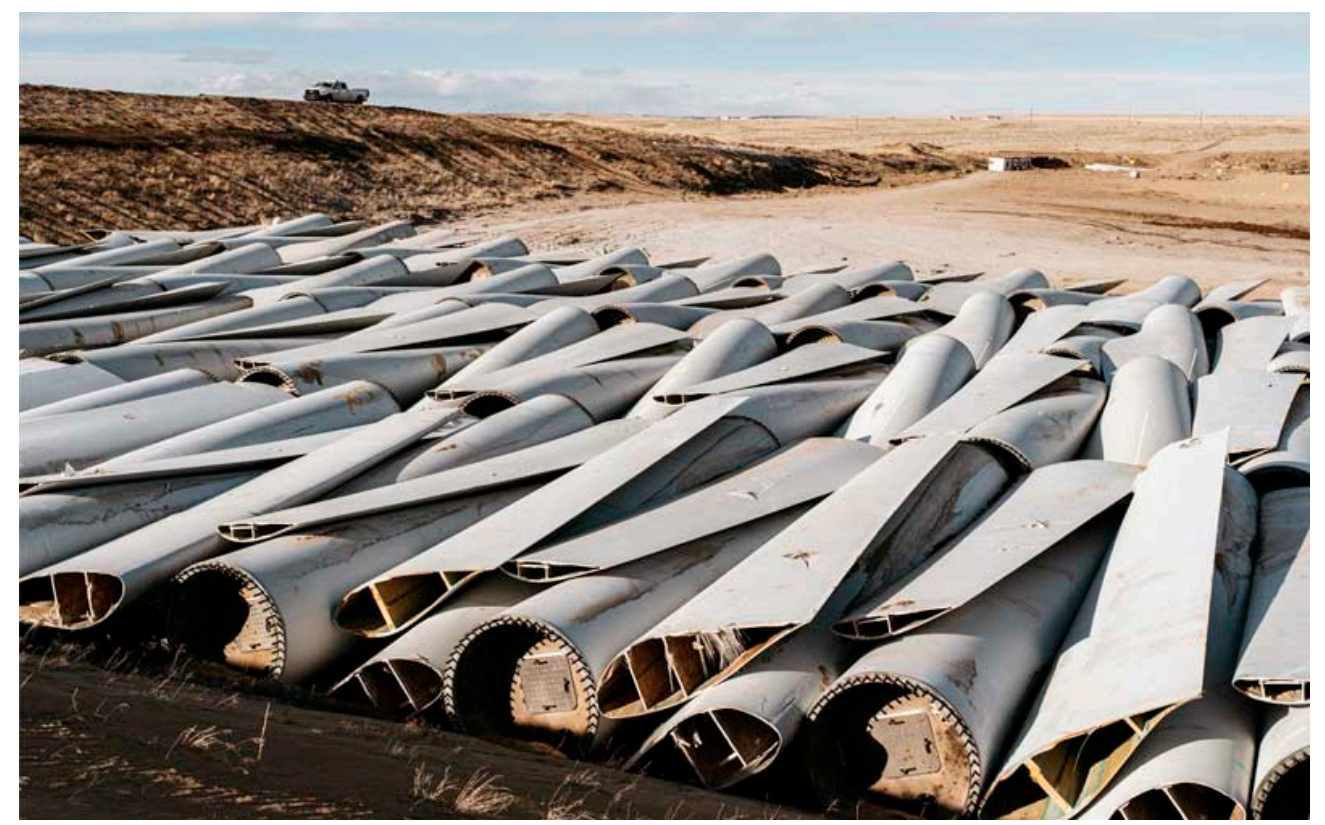

Figure 1. Wind turbine blades in a landfill (adapted from [22]).

The recycling issue has been addressed in Europe through a range of policies for several years now $[23,24]$. Current legislation on the recycling and reuse of composite materials is not very concise. In the case of Europe, in accordance with the Paris Agreement [25], the European Commission intends to reduce greenhouse gas emissions by at least $55 \%$ by 2030 and by at least $80 \%$ by 2050 , both when compared to 1990 levels [26]. Regarding CFRP use and recycling in the automotive industry in the European Union, Directive 2000/53/EC establishes minimum reuse and recovery values of $95 \%$ for all endof-life vehicles and reuse and recycling values of $85 \%$ by an average weight per vehicle per year. $[27,28]$. In order to achieve the proposed sustainability objectives, the industry must address three key points: the processes-improving them to reduce production time; the design-improving the distribution of loads in aerofoils for example; and the development of new materials-employing natural fibers or bio-based polymers [19,29].

Composite materials recycling is a complex issue due to multiple aspects. The use phase of composite materials dominates the life cycle energy consumption, especially for those applications that require an energy input, benefitting from these high-performance materials in terms of reduced consumption and emissions due to weight reduction [30-32]. Such applications include the aerospace industry or the manufacturing of pressure vessels, with an increasing presence of the automotive industry [33-35]. In such applications, the technical requirements are extremely demanding, which has historically justified the lack of incentives for recycling and recovering the waste generated, focusing on performance almost exclusively. Strategies for approaching the reduction of CFRP waste generation 
include, but are not limited to, prevention, minimization, reuse, recycling, energy recovery, and waste disposal, in descending order of priority.

Regarding the use of recycled carbon fiber $(\mathrm{rCF})$, some of the problems that may arise as a result of the different recycling processes may include loss of strength [20,36,37], fiber damage [38,39], variation in fiber length [40-43], changes in fiber diameter [38,44], char deposition [45-47], and contamination on fibers [47-49]. From an environmental point of view, some recycling methods present significant problems of gas emissions [50] or the use of potentially hazardous solvents [42,51].

To approach the problems mentioned above, the issue of CFRP recycling has been approached from different points of view. There are three main recycling methods: mechanical, thermal, and chemical recycling. Mechanical recycling obtains chopped composite materials, while both thermal and chemical recycling aim to recover fibers. Landfilling and incineration, considered as recycling methods, are not sustainable and should be replaced as soon as possible. Pyrolysis is the most commonly used thermal method, allowing to obtain fibers with good mechanical performance if the process is optimized, and obtaining fillers and hydrocarbon liquids and solids as subproducts. Other subprocesses, such as fluidized bed are well established and documented. Chemical recycling consists of the recovery of fibers by degradation of the polymer matrix. Possible routes for degradation include solvolysis, hydrolysis, and glycolysis. These recycling approaches, as well as main techniques, subprocesses, and products obtained, can be observed in Figure 2.

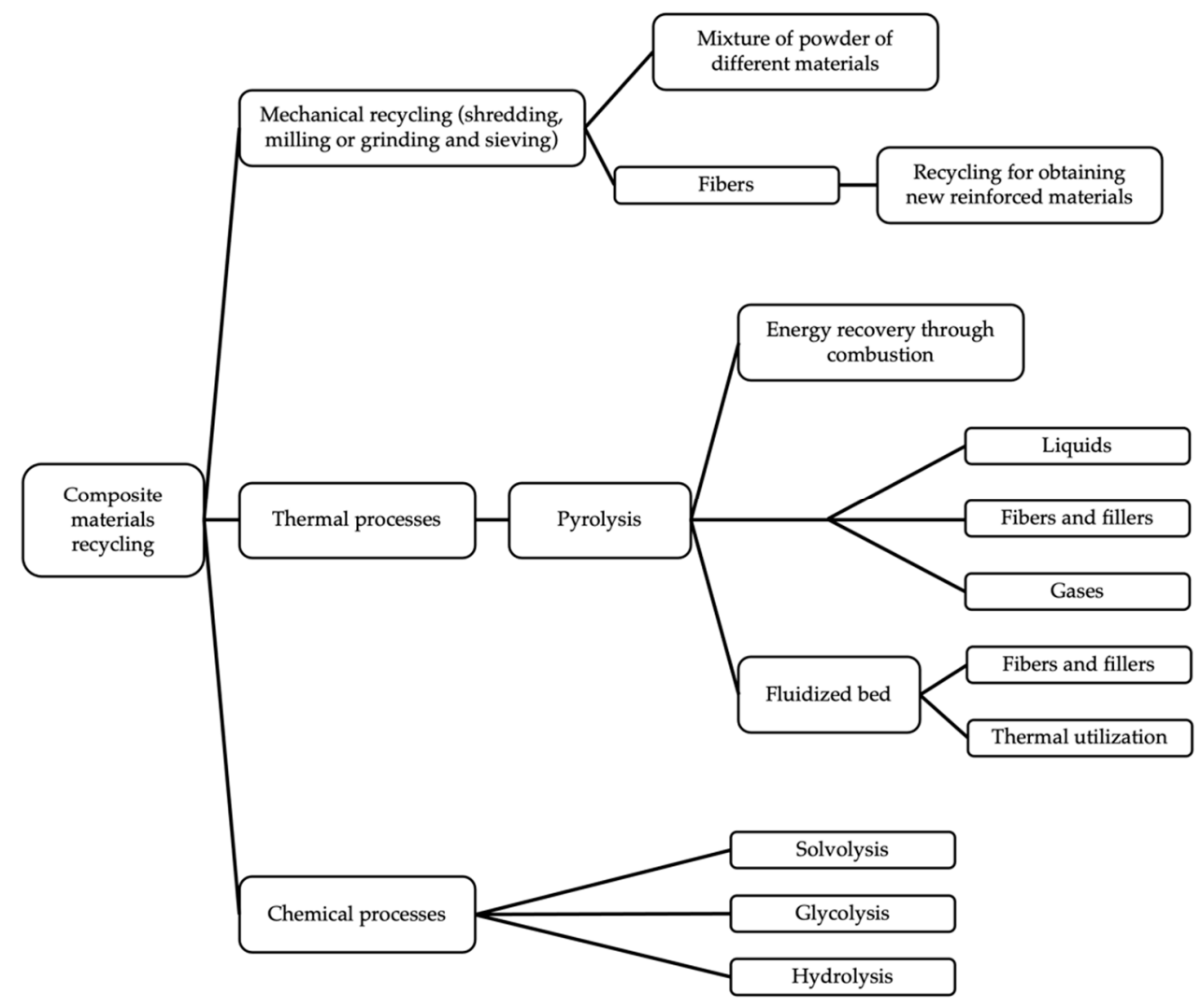

Figure 2. Composite materials recycling alternatives.

\section{Mechanical Recycling}

Mechanical recycling consists of grinding, crushing, grounding, milling, and/or shredding the composite material and using it as a reinforcement with a new matrix. After grinding, sieving is usually carried out to obtain both powdery (resin-rich) and fibrous (fiber-rich) products. Unlike thermal and chemical recycling, mechanical recycling does not generate toxic gases such as carbon monoxide or greenhouse gases such as carbon dioxide. Some of the methods researched in the last years are collected in Table 1. 
Table 1. Mechanical recycling methods.

\begin{tabular}{|c|c|c|c|c|}
\hline Material & Grinding Equipment & Size & Contribution & Ref. \\
\hline $\begin{array}{l}\text { GFR }^{1} \text { polyester, CFR } \\
\text { epoxy and epoxy-based } \\
\text { aramid fibers composites }\end{array}$ & $\begin{array}{l}\text { Mini granulator }+ \\
\text { sieves from } 1 \text { to } \\
5.5 \mathrm{~mm}\end{array}$ & $\begin{array}{l}\text { 4-9 mm length, 8-12 } \mu \mathrm{m} \\
\text { diameter. }\left(1 / \mathrm{d}_{\exp }>1 / \mathrm{d}_{\text {crit }}\right)\end{array}$ & $\begin{array}{l}\text { Introduction of mechanically } \\
\text { recycled fibers in thermoplastic } \\
\text { matrices (ethylene and } \\
\text { methacrylic acid/propylene } \\
\text { copolymer) }\end{array}$ & {$[52]$} \\
\hline CFR epoxy & $\begin{array}{l}\text { Rotating blade with a } \\
\text { sieve/ball mill }\end{array}$ & $\begin{array}{l}1-10 \mathrm{~mm} \\
1-10 \mu \mathrm{m}\end{array}$ & $\begin{array}{c}\mathrm{ABS}^{3} \text { matrix with recycled } \\
\text { CFRP }\end{array}$ & {$[53,54]$} \\
\hline GFR polyester $\left(\mathrm{SMC}^{4}\right)$ & $\begin{array}{l}\text { Hammer mill. Sorting } \\
\text { by air cascade }\end{array}$ & $2-25 \mathrm{~mm}$ & $\begin{array}{l}\text { Introduction of recycled fibers } \\
\text { for } \mathrm{DMC}^{5}\end{array}$ & {$[55]$} \\
\hline $\begin{array}{l}\text { CFR epoxy with different } \\
\text { fiber types (woven, UD }{ }^{6} \\
\pm 45^{\circ} \text { ). Several curing stages }\end{array}$ & $\begin{array}{l}\text { Slow speed granulator } \\
+ \text { sieving }\end{array}$ & $600 \mu \mathrm{m}-11.2 \mathrm{~mm}$ & $\begin{array}{l}\text { Study of granulator } \\
\text { effectiveness }\end{array}$ & {$[56]$} \\
\hline $\begin{array}{l}\text { Commercial rCF (by } \\
\text { depolymerization) }\end{array}$ & - & $7 \mathrm{~mm}$ length & $\begin{array}{c}\text { Enhancement of rCF-matrix } \\
\text { adhesion with plasma } \\
\text { treatments }\end{array}$ & {$[57]$} \\
\hline CFR PEEK 7 & $\begin{array}{l}\text { Electronic equipment } \\
+ \text { sieving }\end{array}$ & $\begin{array}{c}2-10 \mathrm{~mm} \text { length, } 0.16-2 \mathrm{~mm} \\
\text { thickness }\end{array}$ & $\begin{array}{c}\text { Electrodynamical fragmentation } \\
\text { as an alternative to mechanical } \\
\text { shredding }\end{array}$ & {$[58]$} \\
\hline CFR epoxy & Microfine mill & $20-100 \mu \mathrm{m}$ & $\begin{array}{l}\text { Absorption of PMMA }{ }^{8} \text { particles } \\
\text { to improve adhesion with the } \\
\text { new matrix }\end{array}$ & {$[59]$} \\
\hline
\end{tabular}

${ }^{1}$ Glass fiber reinforced; ${ }^{2}$ Carbon fiber reinforced; ${ }^{3}$ Acrylonitrile butadiene styrene; ${ }^{4}$ Sheet moulding compound; ${ }^{5}$ Dough moulding compound; ${ }^{6}$ Uni-directional; ${ }^{7}$ Polyether ether ketone; ${ }^{8}$ Poly(methyl methacrylate).

The main problem with mechanical recycling is the adhesion between the recycled material and the new matrix. Figure 3 exhibits some examples of this issue in the literature. Figure 3a shows a SEM image for epoxy-rCF interface. In Figure 3b, with higher magnification, arrows exhibit complete separation between the epoxy matrix and rCF. Similarly, Figure $3 c$,d displays the fracture surface images of the polypropylene (PP) composite and poor adhesion between $\mathrm{rCF}$ and the matrix due to the agglomerated fibers in the polymeric matrix.
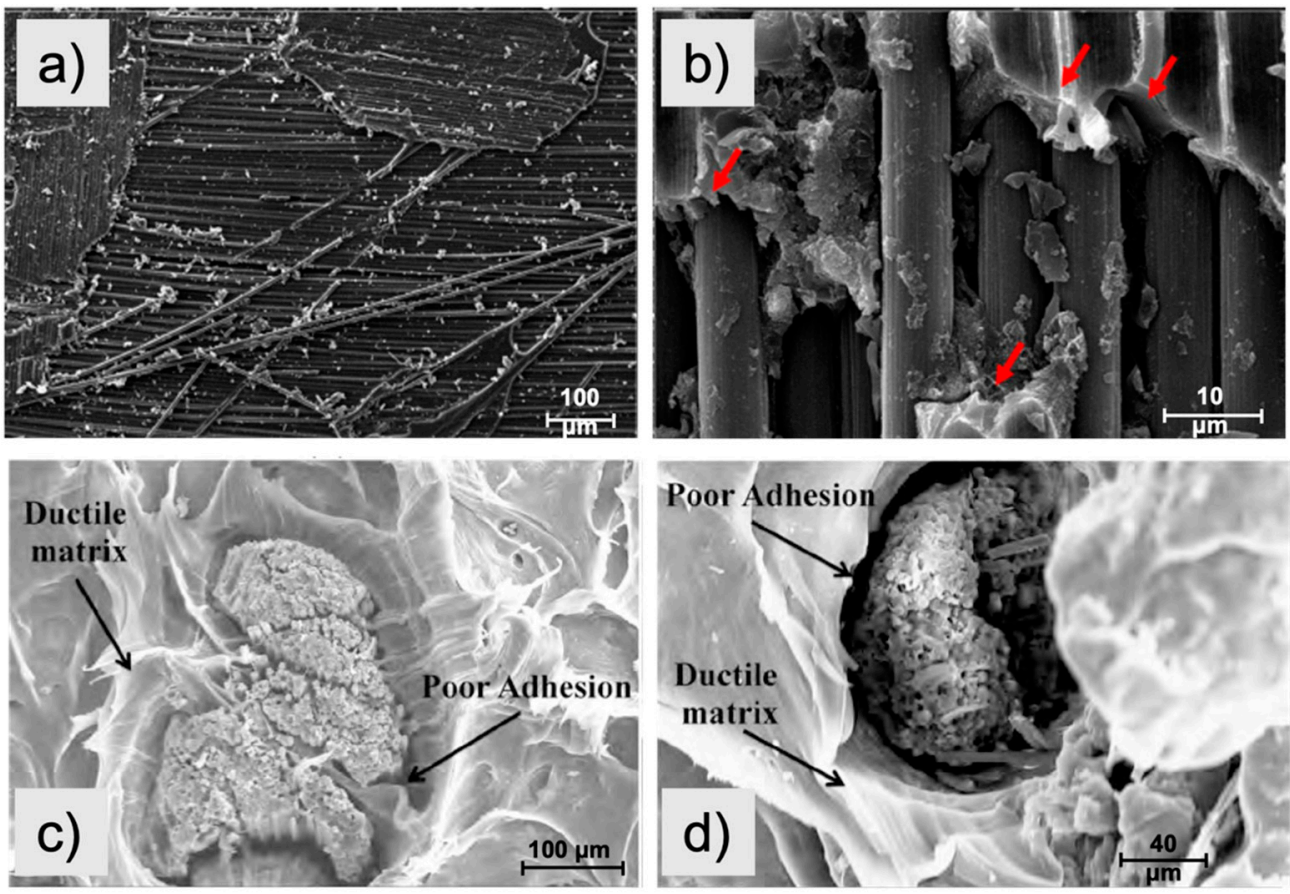

Figure 3. SEM images of the recycled carbon fibers: $(\mathbf{a}, \mathbf{b})$ poor epoxy-rCF interface [60]; $(\mathbf{c}, \mathbf{d})$ poor adhesion between the PP matrix and rCF [61]. 
Okayasu et al. [54] found that when material made from ABS-matrix recycled material was subjected to tensile stresses, failure occurred mainly by pull-out of the fibers in the matrix. Palmer et al. [55] optimized the process of mixing virgin carbon fiber (vCF) and mechanically recycled carbon fiber and manufacturing composites by DMC, reducing the cost of these manufactured composites by minimizing the ratio of $\mathrm{vCF}$ to $\mathrm{rCF}$, while maintaining mechanical properties.

Due to typically damaging fibers and reducing fiber length, mechanical recycling is used as a pre-recycling process for thermal or chemical recycling [20]. The reduction in the mechanical performance of mechanically recycled composites can be explained mainly because the carbon fibers are discontinuous; therefore, recycled composite properties are not comparable to those of long carbon fiber or continuous carbon fiber composites. Chen [62] illustrates the drop in mechanical properties due to shredding, showing a reduction in tensile strength and flexural strength of about $65 \%$ and $85 \%$, respectively. The reduction in modulus of elasticity (MOE) is less pronounced, with a drop in tensile MOE and flexural MOE of $50 \%$.

As an alternative to shredding, Roux et al. [58] used the electrodynamic fragmentation method to reduce door hinges from the aerospace industry. By controlling the applied voltage, they were able to reduce the composite material without mechanical shredding, resulting in a decrease of only $17 \%$ of the mechanical performance compared to the original product. Nonetheless, a continuous flow working machine would be required to implement this process in an industrial application.

\section{Thermal Recycling}

Thermal recycling methods focus on the recovery of the carbon fiber by breaking down the matrix. Pyrolysis and oxidation in fluidized bed are the two most used methods in thermal recycling. Energy recovery is discarded as a recycling method to recover carbon fibers, as all the added value of long carbon fibers compared to short fibers in CFRP manufacturing is lost. A simplified model for pyrolysis is represented in Figure 4.

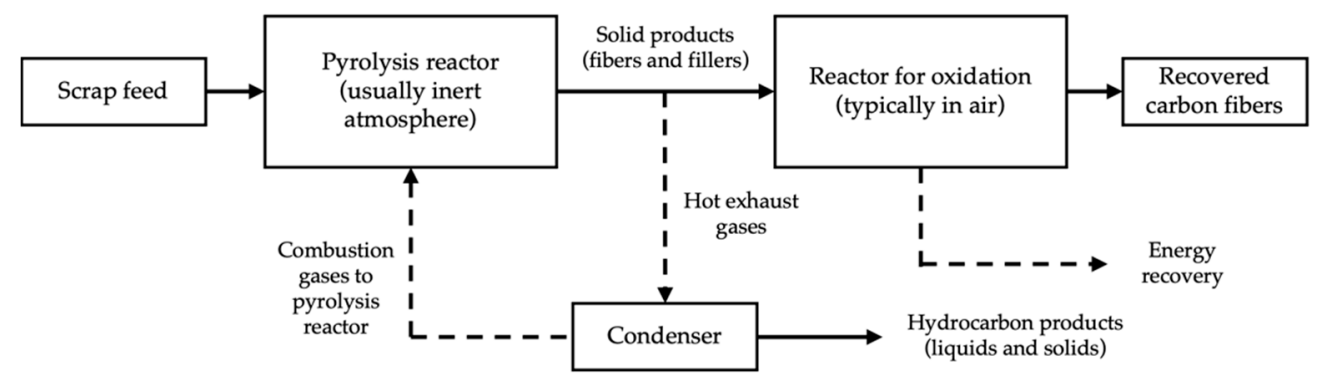

Figure 4. Pyrolysis process (modified from Pickering et al. [63]).

\subsection{Pyrolysis}

In pyrolysis, the CFRP is heated up to the range of 350 to $700{ }^{\circ} \mathrm{C}$ in an inert atmosphere. The composite material decomposes and produces gases, bio-oil and solids (fibers, fillers and carbonaceous residue (char)). The mechanical performance of recovered carbon fibers is highly dependent on the parameters of the process. In this regard, the temperature for the process must be carefully selected attending to the matrix. If this temperature is too low, char remains adhered to the fibers, while temperatures too high produce a decrease in the thickness of fibers. A post-pyrolysis treatment, consisting of oxidation with air, is required to remove the solid carbon contamination, obtaining clean fibers and fillers [64]. This stage may result in a significant loss in the tensile strength of the fibers.

The two main advantages of pyrolysis are the ability to obtain rCF that retain at least 50 to $75 \%$ of the mechanical properties (or a $90-95 \%$ of the mechanical properties if pyrolysis is followed by an oxidation and both processes are optimized) and the possibility to be implemented at a commercial scale. On the downside, pyrolysis requires an inert atmosphere and a complementary oxidation process to improve the mechanical properties 
of the fibers obtained. In addition, the environmental impact of this process, which usually involves maintaining temperatures above $500{ }^{\circ} \mathrm{C}$ and emitting hazardous gases, poses a sustainability problem. Several thermal recycling methods, focusing on pyrolysis, are presented in Table 2.

Table 2. Thermal recycling methods.

\begin{tabular}{|c|c|c|c|c|c|c|c|}
\hline \multirow[b]{2}{*}{ FRP } & \multirow{2}{*}{ Reactor } & \multicolumn{3}{|c|}{ Pyrolysis } & \multirow{2}{*}{ Oxidation } & \multirow[b]{2}{*}{ Contribution } & \multirow[b]{2}{*}{ Ref. } \\
\hline & & $\mathrm{T}\left({ }^{\circ} \mathrm{C}\right)$ & Time & Gas & & & \\
\hline CFR epoxy & Py-GC/MS ${ }^{1}$ & 700 & - & - & - & $\begin{array}{c}\text { Study of two } \\
\text { composite materials }\end{array}$ & [65] \\
\hline CFR epoxy & TGA $^{2}$ & 900 & Variable & $\mathrm{N}_{2}{ }^{3}$ & Air at $600^{\circ} \mathrm{C}$ & $\begin{array}{l}\text { Optimization of the } \\
\text { pyrolysis cycle }\end{array}$ & [66] \\
\hline $\begin{array}{l}\text { CFR polyben- } \\
\text { zoxazine }\end{array}$ & Fixed-bed batch & $350-700$ & $1 \mathrm{~h}$ & $\mathrm{~N}_{2}$ & $\begin{array}{l}\text { Air at } 500 \text { and } \\
700{ }^{\circ} \mathrm{C} \\
\end{array}$ & $\begin{array}{l}\text { Recovery of activated } \\
\text { carbon fibers }\end{array}$ & [47] \\
\hline CFR epoxy & Furnace & 550 & $\begin{array}{l}20 \min 500^{\circ} \mathrm{C}, \\
90 \min 550^{\circ} \mathrm{C}\end{array}$ & $\mathrm{N}_{2}$ & $\begin{array}{c}\mathrm{CO}_{2}^{4}+\mathrm{O}_{2}^{5}+ \\
\text { air }+\mathrm{H}_{2} \mathrm{O}^{6} \text { at } \\
550-700{ }^{\circ} \mathrm{C}\end{array}$ & $\begin{array}{c}\text { Chemical } \\
\text { post-treatment in } \\
\mathrm{HNO}_{3}{ }^{7}\end{array}$ & [67] \\
\hline $\begin{array}{l}\text { CFR epoxy } \\
\text { cured, } \\
\text { uncured and } \\
\text { contaminated }\end{array}$ & $\begin{array}{l}\text { Batch furnace, } \\
\text { commercial } \\
\text { process }\end{array}$ & $<400$ & $\begin{array}{c}\text { Sample } \\
\text { dependent }\end{array}$ & - & - & $\begin{array}{c}\text { PPS }^{8} \text { material } \\
\text { (thermoplastic) with } \\
\text { rCF }\end{array}$ & [68] \\
\hline $\begin{array}{l}\text { CFR polyben- } \\
\text { zoxazine }\end{array}$ & $\begin{array}{l}\text { Pilot-scale } \\
\text { facility }\end{array}$ & $500-700$ & - & - & $\begin{array}{l}\text { Gasification in } \\
\text { air at } 500{ }^{\circ} \mathrm{C}\end{array}$ & Process optimization & [69] \\
\hline CFR epoxy & $\begin{array}{l}\text { Fixed bed } \\
\text { reactor }\end{array}$ & 550 & $30 \mathrm{~min}$ & $\mathrm{H}_{2} \mathrm{O}$ & $\begin{array}{l}\text { Air at } 550{ }^{\circ} \mathrm{C} \\
\text { for } 30 \text { to } 75 \mathrm{~min}\end{array}$ & $\begin{array}{l}\text { Carbon fiber recovery } \\
\text { by super-heated } \\
\text { steam method }\end{array}$ & [70] \\
\hline $\begin{array}{l}\text { Cured and } \\
\text { uncured } \\
\text { epoxy CFR } \\
\text { cuts }\end{array}$ & $\begin{array}{l}\text { Pilot plant } \\
\text { batch }\end{array}$ & 500 & $150 \mathrm{~min}$ & $\mathrm{~N}_{2}$ & $\begin{array}{l}\text { Air at } \\
500-600^{\circ} \mathrm{C} \text { for } \\
10 \text { to } 60 \mathrm{~min}\end{array}$ & $\begin{array}{l}\text { Recovery of recycled } \\
\text { fibers and production } \\
\text { of new composites }\end{array}$ & [71] \\
\hline CFR epoxy & TGA & 500-1000 & Variable & $\begin{array}{l}\mathrm{N}_{2} / \\
\mathrm{CO}_{2}\end{array}$ & - & $\begin{array}{l}\text { Use of } \mathrm{CO}_{2} \text { and water } \\
\text { vapor to remove char }\end{array}$ & [72] \\
\hline CFR epoxy & Furnace & 360 & $80 \mathrm{~min}$ & Air & - & $\begin{array}{l}\text { Carbon fibers } \\
\text { recovery through } \\
\text { catalytic pyrolysis in } \\
\text { molten } \mathrm{ZnCl}_{2}{ }^{9}\end{array}$ & [73] \\
\hline CFR epoxy & $\begin{array}{c}\text { Cone } \\
\text { calorimeter } \\
\text { (batch reactor) }\end{array}$ & 550 & $20-25 \mathrm{~min}$ & - & - & $\begin{array}{l}\text { Recovery of carbon } \\
\text { fibers from discarded } \\
\text { UD composites }\end{array}$ & [45] \\
\hline CFR epoxy & $\begin{array}{l}\text { TGA and } \\
\text { furnace }\end{array}$ & $300-700$ & $60-120 \mathrm{~min}$ & $\mathrm{~N}_{2}$ & - & Process optimization & [74] \\
\hline
\end{tabular}

${ }^{1}$ Pyrolysis-gas chromatography and mass spectrometry; ${ }^{2}$ Thermogravimetric analysis; ${ }^{3}$ Nitrogen; ${ }^{4}$ Carbon dioxide; ${ }^{5}$ Oxygen; ${ }^{6}$ Water;

${ }^{7}$ Nitric acid; ${ }^{8}$ Polyphenylene sulphide; ${ }^{9}$ Zinc chloride.

Nahil et al. [47] proved that by performing pyrolysis at $500{ }^{\circ} \mathrm{C}$, followed by oxidation at $500{ }^{\circ} \mathrm{C}$, it is possible to maintain more than $90 \%$ of the tensile strength and elastic modulus (compared to virgin fibers). Abdou et al. [74] used a TGA for carbon fiber reinforced epoxy, at $550{ }^{\circ} \mathrm{C}$ for $1 \mathrm{~h}$ in a nitrogen atmosphere, to recover carbon fibers with no pores, fracture or carbonization.

Microwave-assisted pyrolysis (MAP) processes consist of heating the material from the inside by means of microwaves, avoiding char formation [75]. The energy consumption of MAP, compared to conventional pyrolysis, tends to be much lower. Hao et al. [76] successfully recovered carbon fibers from prepreg under microwave pyrolysis, followed by oxidation. They observed a strength reduction lower than $20 \%$ compared to the original prepregs, which could be further diminished by reducing the pyrolysis temperature.

$\mathrm{Wu}$ et al. [73] studied the catalytic pyrolysis of carbon fiber reinforced epoxy in molten $\mathrm{ZnCl}_{2}$. They found that the molten salt prevented oxidation during pyrolysis, that the temperature required for pyrolysis was significantly low $\left(380^{\circ} \mathrm{C}\right)$, and that the tensile strength of the recovered fibers was near $95 \%$ of the tensile strength of virgin fibers. 
Despite flexural properties and interlaminar shear strength (ILSS) showing some decrease compared to the composites made with $\mathrm{vCF}$, after a sizing treatment, the properties of these composites were again very similar to those of vCF composites.

\subsection{Fluidized Bed}

Fluidized bed has been developed for the latest 20 years and operates at a pilot-scale. In these processes, the CFRP waste is fluidized typically under pressure $(10-25 \mathrm{kPa})$ by a hot air stream $\left(450-550{ }^{\circ} \mathrm{C}\right)$ in a silica sand bed. The high temperature decomposes the matrix without damaging the fibers, which can be separated and recovered, these being oxidized at a later stage with the gases released by the matrix. Some of the risks involved in this technique are the presence of organic solvents and the emission of polluting gases. Besides the high economic cost of maintaining a continuous stream of hot air, the major drawback of the fluidized bed process is the severe decrease in the mechanical properties of the fibers during recovery.

Pickering et al. [37] built a commercial-scale fluidized bed plant, which resulted in an energy decrease required to obtain $\mathrm{rCF}$ from 90 to $95 \%$ compared to vCF. The fibers obtained only suffered an $18.2 \%$ loss of their tensile strength while maintaining intact their tensile modulus.

\section{Chemical Recycling}

Chemical recycling, along with thermal recycling, is the method in which most research effort is currently being invested. The motivation behind the development of chemical recycling is based on achieving $\mathrm{rCF}$ with unaltered mechanical properties or morphology after recycling, as well as reducing the high energy consumption of thermal recycling [77]. The best mechanical performance for $\mathrm{rCF}$ is usually achieved by chemical recycling methods. Some of the factors that influence the outcome of the process are temperature, pressure, catalysts, and solvents used. The temperatures used in the different techniques that can be grouped into chemical recycling are generally lower than $400{ }^{\circ} \mathrm{C}$. Solvolysis processes can be divided according to their requirements: higher temperature $\left(>200^{\circ} \mathrm{C}\right)$ and high pressure or lower temperature $\left(<200^{\circ} \mathrm{C}\right)$ and low pressure [78].

The degradation of the resin can be achieved by means of water (hydrolysis) or solvents (solvolysis). To minimize the environmental problems as well as the harmfulness and toxicity of hazardous and concentrated chemicals, much research is focused on the use of subcritical or supercritical water and alcohol as a substitute for these chemicals. Some possibilities for matrix decomposition include depolymerization or alkaline digestion, in which benzyl alcohol and tripotassium phosphate are used; acid digestion, using acetic acid and hydrogen peroxide to remove the epoxy resin; and sub- (low pressure and temperature) and supercritical (high pressure and temperature) fluids, employing water, ethanol, methanol, propanol or potassium hydroxide $[49,79,80]$. Besides the hazardous nature of the products used, the main disadvantage of chemical recycling is the very high difficulty of bringing these processes to a commercial scale. Diverse chemical methods studied in the last years are included in Table 3.

Sun et al. [46] proposed an electrochemical method for carbon fiber recycling from CFRP as a simple, effective, and economical recycling method. By identifying the parameters that affect recycling efficiency, they determined that an increase in electrolyte concentration does not yield better results in terms of efficiency. Moreover, the surface chemistry showed a loss of $\mathrm{rCF}$ crystallinity compared to that of $\mathrm{vCF}$. The recycling rate, understood as the ratio of recycled depth to time, is extremely low.

Several authors have investigated the use of supercritical solvents, particularly acetone. One of the drawbacks of using sub- or supercritical solvents is the energy required to bring them to that state, either by pressure, temperature, or a combination of both. Okajima et al. [90] employed supercritical methanol, 1-propanol, 2-propanol, 1- butanol, 2-butanol, tert-butanol, acetone, and methyl ethyl ketone. While the results depend on the solvent, sub- and supercritical acetone were selected as optimal for rapidly degrading the 
matrix. Carbon fibers recovered with supercritical acetone maintain the tensile strength, and no matrix residues are observed on the fibers. Sokoli et al. [92] used supercritical acetone to recover glass fibers and carbon fibers from FRPs. While the recovered glass fibers had matrix residues in the fibers, the carbon fibers were recovered perfectly clean, with their mechanical properties intact. The authors point out the possibility of upscaling solvolysis processes, as all product streams are potentially reusable.

Table 3. Chemical recycling methods.

\begin{tabular}{|c|c|c|c|}
\hline Chemical Agents & Reaction Conditions & Tensile Strength Retention & Ref. \\
\hline Nearcritical and supercritical water & $250-400{ }^{\circ} \mathrm{C}, 4-27 \mathrm{MPa}, 1-30 \mathrm{~min}$ & $90-98 \%$ & [81] \\
\hline Water + benzyl alcohol & $400^{\circ} \mathrm{C}, 1 \mathrm{~h}$ & - & [79] \\
\hline $\mathrm{NaCl}^{1}$ dissolution & Electrochemical (4-25 mA) & $80 \%$ & [46] \\
\hline Hydrochloric acid in tetrahydrofuran & Room temp., $24 \mathrm{~h}$ & Similar to virgin fibers & [82] \\
\hline $\mathrm{AlCl}_{3}{ }^{2}+$ Acetic acid & $180^{\circ} \mathrm{C}, 6 \mathrm{~h}$ & $97.77 \%$ & [83] \\
\hline Ethylene glycol & $180^{\circ} \mathrm{C}, 4 \mathrm{~h}$ & $95 \%$ & [84] \\
\hline Supercritical 1-propanol with $1 \% \mathrm{KOH}^{3}$ & $330^{\circ} \mathrm{C}, 1 \mathrm{~h}$ & $94.6 \%$ & [85] \\
\hline $\begin{array}{l}\text { Sub- and supercritical water and } \\
\text { water/ethanol (50:50) }\end{array}$ & $350-400{ }^{\circ} \mathrm{C}, 25 \mathrm{MPa}$ & Similar to desized virgin fibers & [86] \\
\hline $\begin{array}{c}\mathrm{ZnCl}_{2 / \mathrm{KOH} / \mathrm{HPW}}{ }^{4} / \mathrm{MgCl}_{2} \\
5 / \mathrm{AlCl}_{3} / \mathrm{FeCl}_{3}{ }^{6}+\text { ethanol/water }\end{array}$ & $80-250{ }^{\circ} \mathrm{C}, 2-10 \mathrm{~h}$ & - & [87] \\
\hline Water/acetone (20:80) & $320^{\circ} \mathrm{C}, 60 \mathrm{~min}$ & $>90 \%$ & [88] \\
\hline Supercritical n-butanol & $360^{\circ} \mathrm{C}, 1 \mathrm{~h}$ & $98.63 \%$ & [89] \\
\hline Supercritical acetone & $320^{\circ} \mathrm{C}, 20 \mathrm{~min}$ & Negligible decrease & [90] \\
\hline $\begin{array}{l}\text { Subcritical water } \\
\text { Supercritical water }\end{array}$ & $\begin{array}{l}400^{\circ} \mathrm{C}, 15 \mathrm{~min} \\
280^{\circ} \mathrm{C}, 30 \mathrm{~min}\end{array}$ & $>90 \%$ & [91] \\
\hline Peracetic acid (acetic acid $+\mathrm{H}_{2} \mathrm{O}_{2}{ }^{7}$ ) & $65^{\circ} \mathrm{C}, 4 \mathrm{~h}$ & Similar to virgin fibers & [48] \\
\hline Nearcritical water and supercritical acetone & $260-300{ }^{\circ} \mathrm{C}, 6-30 \mathrm{MPa}$ & Similar to virgin fibers & [92] \\
\hline Superheated and supercritical acetone & $350^{\circ} \mathrm{C}, 2-14 \mathrm{MPa}, 60 \mathrm{~min}$ & - & [93] \\
\hline $\begin{array}{l}\text { Benzyltrimethylammonium bromide } \\
\text { (BTAB) and sodium dodecyl sulfate (SDS) }\end{array}$ & Process: $100^{\circ} \mathrm{C}, 1 \mathrm{hDry}: 100^{\circ} \mathrm{C}, 24 \mathrm{~h}$ & $96.9 \%$ & [94] \\
\hline
\end{tabular}

Das et al. [48] investigated the use of peracetic acid, formed from a mixture of acetic acid and hydrogen peroxide, as an oxidative method to recover carbon fibers from CFRP composites. The surface of $\mathrm{rCF}$ is clean, and the tensile strength is comparable to that of $\mathrm{VCF}$. In addition, the solvents are recovered in pure and reusable form with a recovery efficiency above $90 \%$. Coupled with the fact that the method does not require high temperatures and pressures, it results in a lower environmental impact.

Khalil [95] compared seventeen supercritical fluids commonly used for depolymerizing thermoset resins in CFRP waste, providing numerical examples to demonstrate that higher reaction temperature and pressure in solvolysis leads to higher resin removal efficiency but also leads to a much bigger environmental footprint. The study ranked supercritical fluids in terms of cradle-to-gate (C2G) production energy intensity, finding supercritical mixtures of solvents and water more effective in the recovery of carbon fibers but also requiring less production energy intensity, therefore causing lesser environmental footprint. Once again, the main disadvantage of chemical recycling is the very high difficulty of bringing these processes to a commercial scale. 


\section{Reuse of Recycled Carbon Fibers}

Aiming towards the objectives of a circular economy, carbon fiber recovery is a key factor. In terms of costs and energy, the recovery and reuse of $\mathrm{rCF}$ are perfectly justified. While producing $\mathrm{VCF}$ is an energy-intensive process, the energy cost of recycling carbon fibers can be $82-98 \%$ lower, therefore leading to a significant cost reduction [96]. Since the mechanical properties of $\mathrm{rCF}$ are not much lower than those of $\mathrm{vCF}$, CFRP manufactured with $\mathrm{rCF}$ (rCFRP) can achieve even higher values of tensile strength or impact resistance compared to commercial CFRP. Those rCFRPs are typically manufactured by compression moulding, injection moulding, or autoclave moulding. These main composite manufacturing processes and their typical steps are reviewed in Figure 5.

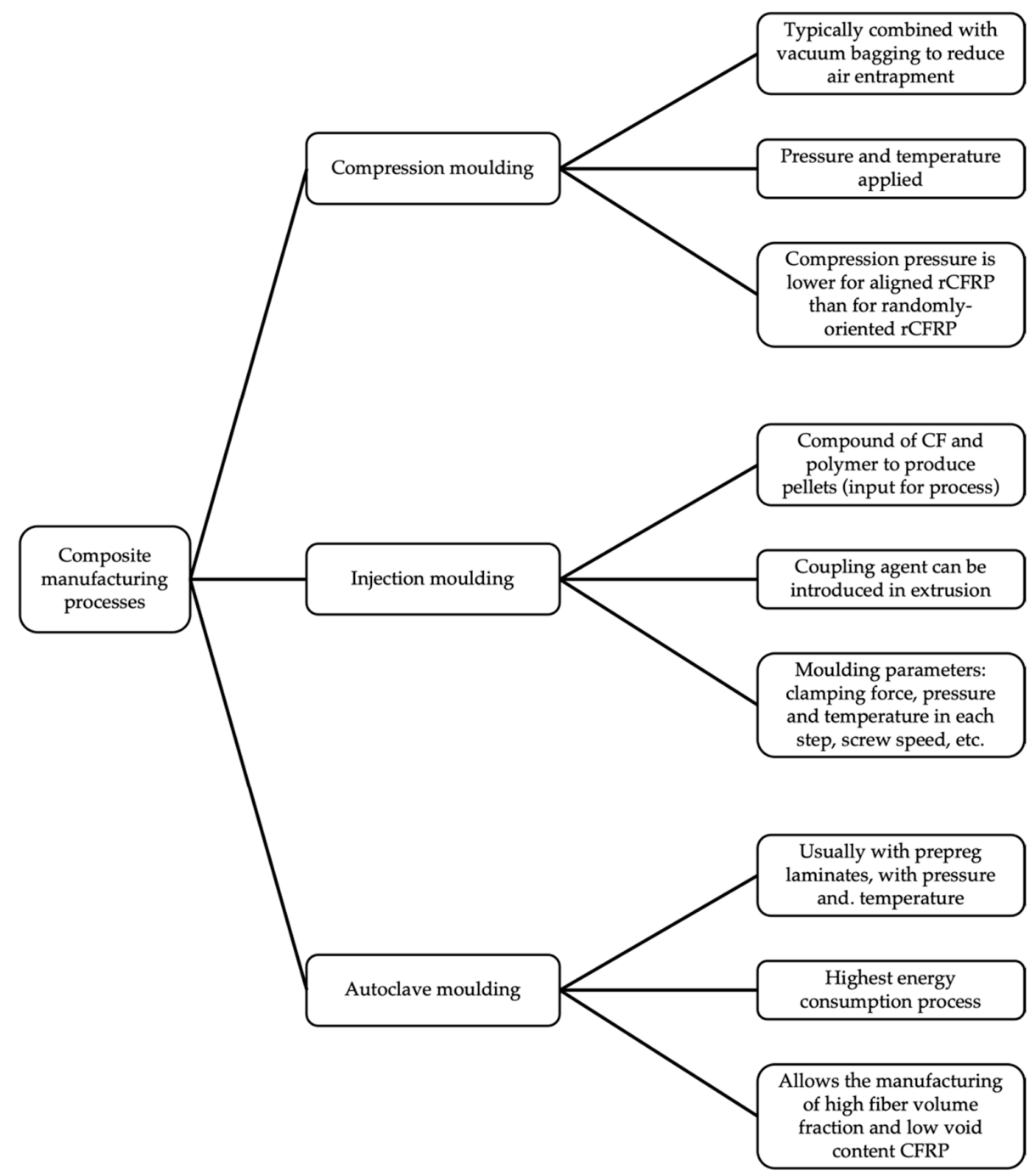

Figure 5. Most common composite manufacturing processes for rCFRP (adapted from Meng et al. [30]).

The mechanical performance of rCFRP is deeply influenced by two factors: fiber length and wettability/adhesion between fiber and matrix. Carbon fiber length is affected by recycling processes, either by controlled cutting before the recycling (to recycle, the CFRP has to fit in an oven for pyrolysis, in a reactor, etc.) or after, or because carbon fibers break down during recycling. Matrices can be thermoset polymers or thermoplastic polymers.

As thermosets, epoxy and polyester have been the most used polymers. CFR thermoset polymers are usually manufactured by compression moulding or autoclave moulding. Sukanto et al. [97] enumerate three different automotive components manufactured with rCF: bulk moulded compounds (BMC) in the form of epoxy resin and calcium carbonate 
$\left(\mathrm{CaCO}_{3}\right)$ mixture; a sheet moulded compound (SMC), filler-epoxy; and prepregs, rCF-epoxy resin. Gopalraj et al. [45] obtained rCFs and recycled glass fibers with a cone calorimeter setup, achieving a recovery rate of $\mathrm{rCFs}$ of $95-98 \%$ in weight. Those $\mathrm{rCFs}$ were then used to manufacture unidirectional CFRP with an epoxy resin, successfully achieving the closed-loop recycling. Mantelli et al. [98] successfully used 3D printing of $\mathrm{rCF}$. They shredded pyrolyzed $\mathrm{rCF}$ with a sizing treatment and used those shreds as a reinforcement of a thermally and photo-curable thermoset resin. The authors point out that a better fiber-matrix adhesion could be achieved by selecting a specifically designed sizing agent. Some examples of the use and reuse of recycled carbon fibers and recycled carbon fiber reinforced polymers are shown in Table 4.

Table 4. General characteristics, manufacturing conditions, and mechanical properties in the reuse of recycled CF and CFRP.

\begin{tabular}{|c|c|c|c|c|c|}
\hline Feedstock & Recycling Process & $\begin{array}{l}\text { New Matrix } \\
\text { Material }\end{array}$ & $\begin{array}{l}\text { Conditions for } \\
\text { Manufacturing }\end{array}$ & $\begin{array}{l}\text { Mechanical Properties } \\
\text { (rCF or Composite) }\end{array}$ & Ref. \\
\hline CFR epoxy & Crushing & $\mathrm{ABS} / \mathrm{PP}{ }^{1}$ & $\begin{array}{l}\text { Pelletizing of CFRTP (CFRP + } \\
\text { thermoplastic polymer) using } \\
\text { a two-axis pelletizing } \\
\text { machine, followed by } \\
\text { injection moulding }\end{array}$ & $\begin{array}{c}\text { Composite: } 24 \% \text { fiber } \\
\text { volume fraction seems to } \\
\text { be a limit for mechanical } \\
\text { properties }\end{array}$ & [99] \\
\hline CFR epoxy & Mechanical cutting (chopping) & Epoxy & $\begin{array}{c}\text { Fibers are converted to } \\
\text { non-woven mats by a wet } \\
\text { papermaking process. } \\
\text { Compression moulding at } \\
7 \mathrm{MPa}\end{array}$ & $\begin{array}{l}\text { rCF: } 98.1 \% \mathrm{TS}^{1}, 95.6 \% \\
\mathrm{TM}^{2} \text { compared to virgin } \\
\text { fibers }\end{array}$ & {$[38]$} \\
\hline $\begin{array}{l}\text { CFR epoxy and } \\
\text { CFR bismaleimide }\end{array}$ & $\begin{array}{l}\text { Mechanical cutting, pyrolysis at } \\
400{ }^{\circ} \mathrm{C} \text {, cleaning with water } \\
\text { washing, including } \\
\text { ultrasonication + fiber drying }\end{array}$ & PPS & $\begin{array}{l}\text { Pelletizing using twin-screw } \\
\text { extruder: throughput } 3 \mathrm{~kg} / \mathrm{h} \text {, } \\
\text { screw speed } 150 \mathrm{rpm} \text {, die } \\
\text { temperature } 315^{\circ} \mathrm{C} \text { and } \\
\text { cooling in air. } \\
\text { Manufacturing by moulding } \\
\text { press at } 290-305^{\circ} \mathrm{C}\end{array}$ & $\begin{array}{c}\text { Composite: } 680 \% \text { TM, } \\
720 \% \text { TS, } 250 \% \text { impact } \\
\text { energy increase, when } \\
\text { compared to PPS }\end{array}$ & {$[68]$} \\
\hline CFR epoxy & $\begin{array}{l}\text { Total cure of prepregs for } 5 \mathrm{~h} \text { at } \\
100^{\circ} \mathrm{C} \text {. Mechanical shredding } \\
\text { and sieving. Fluidized bed at } \\
550{ }^{\circ} \mathrm{C} \text {, followed by oxidation at } \\
850^{\circ} \mathrm{C}\end{array}$ & PP & $\begin{array}{c}\text { Compounding: using } \\
\text { twin-screw extruder, L/D } \\
\text { ratio } 25: 1 \text {, screw speed } 50 \\
\text { (lower fiber damage)-80 rpm, } \\
\text { coupling agents }(2-8 \% \text { ) } \\
\text { Injection moulding: nozzle } \\
\text { temperature } 200-210^{\circ} \mathrm{C}, \\
\text { mould temperature } 50{ }^{\circ} \mathrm{C}, \\
\text { hold pressure } 12 \mathrm{MPa}, \text { back } \\
\text { pressure } 47.5 \mathrm{MPa}\end{array}$ & $\begin{array}{c}\text { Composite: } 150 \% \text { TS } \\
\text { increase when } \\
\text { incorporating coupling } \\
\text { agents ( } 5 \% \text { wt.) } \\
\text { compared to composite } \\
\text { with no coupling agents }\end{array}$ & [100] \\
\hline $\begin{array}{l}\text { rCF from CFR } \\
\text { epoxy }\end{array}$ & $\begin{array}{l}\text { As-received: Pyrolysis at } 500{ }^{\circ} \mathrm{C} \\
\text { for } 10 \mathrm{~min} \text {, and cut }\end{array}$ & PP & $\begin{array}{l}\text { Carding and wrap spinning } \\
\text { process. Hot compression } \\
\text { moulding, at } 220^{\circ} \mathrm{C}, 2 \mathrm{MPa} \\
\text { for } 15 \mathrm{~min}\end{array}$ & $\begin{array}{l}\text { rCF: retains } 90 \% \text { TS and } \\
93 \% \text { TM compared to vCF } \\
\text { Composite: rCFRP with } \\
27.7 \% \text { volume fraction } \\
\text { has } 50 \% \text { higher TS and } \\
\text { FS }^{3} \text { compared to rCFRP } \\
\text { with } 15 \% \text { volume fraction }\end{array}$ & [101] \\
\hline CFR epoxy & $\begin{array}{l}\text { Crushed using rotating blade, } \\
\text { ball milling process }\end{array}$ & ABS & $\begin{array}{l}\text { Mixing, grinding and } \\
\text { injection }\end{array}$ & $\begin{array}{c}\text { Composite: Higher TS } \\
\text { when higher content in } \\
\text { CF, but drops } \\
\text { dramatically at } 70 \% \\
\text { (in weight) }\end{array}$ & {$[54]$} \\
\hline CFR epoxy & $\begin{array}{l}\text { Mechanical cutting, pyrolysis at } \\
500{ }^{\circ} \mathrm{C} \text { followed by oxidation at } \\
500 / 600^{\circ} \mathrm{C}\end{array}$ & Epoxy & $\begin{array}{l}\text { rCF chopping, oxidation } \\
\text { (optional), mixing with epoxy } \\
\text { resin and hot pressing at } \\
110{ }^{\circ} \mathrm{C}, 4.5 \mathrm{MPa} \text {, for } 40 \mathrm{~min}\end{array}$ & $\begin{array}{l}\text { rCF: } 65-95 \% \text { TS when } \\
\text { compared to vCF }\end{array}$ & [102] \\
\hline CFR epoxy & $\begin{array}{l}\text { Solvolysis in water and acetone } \\
\qquad(20: 80 \text { in volume) }\end{array}$ & Epoxy & $\begin{array}{l}\text { For rCF: manually alignment, } \\
\text { impregnation with resin, and } \\
\text { vacuum in bag. Cured at } \\
\text { room temperature for } 16 \mathrm{~h} \\
\text { and post-cured at } 75-80^{\circ} \mathrm{C} \\
\text { for } 1 \mathrm{~h} \\
\text { For rCF plies: alignment, } \\
\text { impregnation with resin, } \\
\text { followed by curing in hot } \\
\text { press at } 60^{\circ} \mathrm{C}, 3.5 \mathrm{MPa} \text {, for } 5 \mathrm{~h}\end{array}$ & $\begin{array}{c}\text { rCF: }>90 \% \text { TS, compared } \\
\text { to vCF }\end{array}$ & {$[88]$} \\
\hline
\end{tabular}


Table 4. Cont.

\begin{tabular}{|c|c|c|c|c|c|}
\hline Feedstock & Recycling Process & $\begin{array}{l}\text { New Matrix } \\
\text { Material }\end{array}$ & $\begin{array}{l}\text { Conditions for } \\
\text { Manufacturing }\end{array}$ & $\begin{array}{l}\text { Mechanical Properties } \\
\text { (rCF or Composite) }\end{array}$ & Ref. \\
\hline $\begin{array}{c}\text { CFR } \\
\text { polybenzoxazine }\end{array}$ & $\begin{array}{l}\text { Mechanical crushing, followed } \\
\text { by pyrolysis at } 500{ }^{\circ} \mathrm{C}\end{array}$ & $\mathrm{LDPE}^{4}$ & $\begin{array}{l}\text { For blending, roll mill: speed } \\
10-20 \mathrm{rpm} \text {, roll temperature } \\
150-180^{\circ} \mathrm{C} \text {. Grounded and } \\
\text { hot pressed at } 34.5 \mathrm{MPa} \text { at } \\
180^{\circ} \mathrm{C}\end{array}$ & $\begin{array}{l}\text { rCF: Some combinations } \\
\text { of rCF + additives show } \\
\text { similar properties to vCF } \\
\text { composites }\end{array}$ & [103] \\
\hline CFR PEEK & $\begin{array}{l}\text { Electrodynamical } \\
\text { fragmentation, } 6 \text { cycles of } 100 \\
\text { pulses, } 180 \mathrm{kV} \text {, frequency } 5 \mathrm{~Hz} \text {, } \\
\text { followed by sieving }\end{array}$ & PEEK & $\begin{array}{c}\text { Compression moulding, } \\
20 \text { ton clamping force, heated } \\
\text { at } 360^{\circ} \mathrm{C} \text { for } 3 \mathrm{~min} \text {, cooled at } \\
\text { a rate of } 20^{\circ} \mathrm{C} / \mathrm{min}\end{array}$ & $\begin{array}{c}\text { Composite: rCFRP } \\
\text { mechanical performance } \\
\text { is } 17 \% \text { lower than novel } \\
\text { composite }\end{array}$ & {$[58]$} \\
\hline PAN-rCF & Unknown & $\mathrm{PC}^{5}$ & $\begin{array}{l}\text { Pelletizing using twin-screw } \\
\text { extruder: screw speed } \\
100 \mathrm{rpm} \text {, die temperature } \\
230-250^{\circ} \mathrm{C} \text {. Injection } \\
\text { (biocarbon fillers }+\mathrm{rCF} \text { ) at } \\
80-120 \mathrm{MPa} \text {, at } 250^{\circ} \mathrm{C}\end{array}$ & $\begin{array}{c}\text { Composite: } 35 \% \text { TM } \\
270 \% \text { TS increase, } \\
\text { compared to the reference } \\
\text { PC-biocarbon composite }\end{array}$ & [104] \\
\hline CFR epoxy & $\begin{array}{l}\text { Pyrolysis in molten } \mathrm{ZnCl}_{2} \text { at } \\
\qquad 360^{\circ} \mathrm{C}\end{array}$ & Epoxy & $\begin{array}{l}\text { Manual lay-up, cured at } 80{ }^{\circ} \mathrm{C} \\
\text { for } 2 \mathrm{~h} \text { and at } 150{ }^{\circ} \mathrm{C} \text { for } 4 \mathrm{~h} \\
\text { in oven. }\end{array}$ & $\begin{array}{l}\text { rCF: } 95 \% \text { TS retention } \\
\text { after pyrolysis in molten } \\
\mathrm{ZnCl}_{2}, 80 \% \text { TS retention } \\
\text { after pyrolysis in air, } \\
\text { compared to vCF }\end{array}$ & {$[73]$} \\
\hline $\mathrm{rCF}$ & $\begin{array}{l}\text { Pyrolysis. Two treatments } \\
\text { for resizing: } \\
\text { Acetone washing and drying } \\
\text { in oven } \\
\text { Acidic treatment in a bath of } \\
65 \% \mathrm{HNO}_{3} \text { for } 20 \mathrm{~min} \text { at } 60{ }^{\circ} \mathrm{C} \text {, } \\
\text { followed by drying in oven }\end{array}$ & $\mathrm{PP} / \mathrm{PA}^{6}{ }^{6}$ & $\begin{array}{l}\text { Preparation of films with } \\
1-5 \% \text { (in weight) of solids } \\
\text { content. Drying for } 12 \mathrm{~h} \text { at } \\
80^{\circ} \mathrm{C} \text {. Chopping of fibers. } \\
\text { Compounding in a } \\
\text { twin-screw } \\
\text { microcompounder at } 80 \mathrm{rpm} \text {, } \\
190^{\circ} \mathrm{C} \text { for PP, } 230^{\circ} \mathrm{C} \text { for PA6, } \\
\text { compounding time } 1 \text { min }\end{array}$ & $\begin{array}{l}\text { Composite: No effect of } \\
\text { PP sizing, slight positive } \\
\text { effect of PU }{ }^{7} \text { sizing on TS } \\
\text { and TM }\end{array}$ & {$[105]$} \\
\hline
\end{tabular}

\footnotetext{
${ }^{1}$ Tensile strength; ${ }^{2}$ Tensile modulus; ${ }^{3}$ Flexural strength; ${ }^{4}$ Low density polyethylene; ${ }^{5}$ Polycarbonate; ${ }^{6}$ Polyamide $6 ;{ }^{7}$ Polyurethane.
}

Roux et al. [58] fragmented carbon fiber reinforced PEEK from an aerospace application (door hinges) via electrodynamical fragmentation and then manufactured new door hinges by compression moulding. The results show that this method improves mechanical performance compared to composites manufactured with $\mathrm{rCF}$ obtained by other mechanical methods, especially for aerospace applications. Huang et al. [106] recovered carbon fibers by means of a supercritical fluid and manufactured composites with an additive manufacturing-based approach. After recovering carbon fibers by supercritical fluid and grounding the rCFs, an extruder was used for obtaining $\mathrm{rCF} / \mathrm{PEEK}$ composite filaments. For the fabrication, those filaments were then fed to a 3D printer.

As observed in the abovementioned examples, thermoplastic matrices can be used in industries such as aerospace or the automotive industry, normally for non-critical, nonstructural parts. The application of thermoplastic polymers as matrices along with $\mathrm{rCF}$ or rCFRP leads to several advantages [107]. Thermoplastic matrices can benefit from the many advantages carbon fibers can offer in terms of mechanical, thermal, or electrical properties. Carbon fiber reinforced thermoplastic (CFRTP) composites can be recycled and reformed. This is a key insight since the amount of CFRTP to be recycled grows every day due to the increasing use in aerospace, automotive or chemical industries. As mentioned above, the cost of $\mathrm{rCF}$ is significantly lower than that of $\mathrm{vCF}$, thus allowing potential entry to a greater number of markets.

On the other hand, carbon fibers have poor wettability and adhesion to thermoplastic matrices, therefore requiring surface treatments or the use of different substances $[100,103]$. The presence of residual solvent in the carbon fibers, used to decrease the processing cost, is a disadvantage that leads to a reduction in the performance of CFRTP.

\section{Conclusions}

In this report, current processes and methods for recycling composites have been reviewed, distinguishing between those aiming to obtain chopped composite materials and 
those whose objective is to recover carbon fibers. Mechanical recycling is not as attractive as it used to be as a process but still retains importance as a pre-treatment as part of thermal or chemical recycling methods. Thermal and chemical processes are nowadays receiving almost all the attention in terms of research and investment. Mechanical performance of recovered carbon fibers through thermal and chemical methods is typically higher than that of mechanically recovered carbon fibers.

One of the most essential issues with mechanical recycling is the adhesion between the recycled material and the new matrix. Since fiber length is usually reduced and fibers might suffer damage from mechanical recycling, much added value is lost by mechanical recycling. Other methods, such as electrodynamical fragmentation, are being studied more intensely.

Thermal recycling methods succeed in recovering carbon fibers by means of heat, being pyrolysis the most employed method. Carbon fibers recovered through pyrolysis in an inert atmosphere require an oxidation process afterwards to achieve optimal performance. Alternatives like MAP are also being developed. Fluidized bed processes allow the recovery of fibers in a very efficient way in terms of energy consumption, but the fibers recovered are fluffy. Energy recovery is discarded as a recycling method to recover carbon fibers, as all the added value of long carbon fibers compared to short fibers in CFRP manufacturing is lost.

The best mechanical performance for rCF is usually achieved by chemical recycling methods. The degradation of the resin is possible by hydrolysis, solvolysis and glycolysis. Due to the lower energy consumption compared to pyrolysis, much research is focused on reducing the environmental impact of chemical recycling. In that regard, the use of subcritical or supercritical water and alcohol as a substitute for hazard and concentrated chemicals is being studied.

The reuse of rCF is critical for a circular economy approach. rCFs are cheaper to produce compared to vCFs, both in terms of cost and energy consumption. By selecting the most appropriate recycling method and a matrix suitable for the wanted application, rCFRPs can successfully be implemented in most industries for non-critical, non-structural applications. The manufacturing processes that can be used with rCFRP include, but are not limited to, wet lay-up, prepreg lamination, injection moulding, compression moulding, 3D printing or resin transfer moulding (RTM).

The most significant research gaps that have been identified in this report are highlighted below.

- Composite waste does not have a homogeneous composition, neither in terms of matrices nor in terms of reinforcements. Neither does it come in a homogeneous type, being able to find cured/partially cured prepregs, loose fibers and recycled composites or fibers. This makes adapting the process conditions and material a challenging task.

- The lack of adhesion between matrix and recycled fibers prevents a greater use of these. New approaches that improve fiber-matrix adhesion or modifications to the current processes are required to solve this critical issue.

- Processes such as electrodynamical fragmentation or microwave-assisted pyrolysis require further research before being optimized and made applicable on an industrial scale.

- $\quad$ Processes such as fluidized bed or solvolysis using solvents in critical conditions still require extensive research before being fully functional on a commercial scale.

- Economic and energy analysis of thermal and chemical processes should be studied in more depth. Simulation models can be developed and used to include all phases in cradle-to-cradle life cycle assessment and to obtain a more accurate cost assessment against which to compare viable processes.

To summarize, CFRP recycling faces three key issues. First, the reduction in fiber length as a result of recycling processes reduces the performance of rCF compared to vCF. Then, energy recovery as a recycling method not only fails to recover the energy invested in the production of the composite material but also results in the total loss of the added value 
that the long carbon fibers provide. Finally, the adhesion between the new matrix and the rCFs is not ideal, which leads to the sub-optimal behavior of composites made with rCFs. With the demand for CFRP increasing every year and due to the significant environmental impact of these materials at the end of life, research is progressing to overcome these issues.

Author Contributions: Conceptualization and methodology, J.A.B., J.A. and M.Á.M.; writingoriginal draft preparation, J.A.B.; writing-review and editing, J.A.B., M.B., J.A. and M.Á.M.; supervision, M.B., J.A. and M.Á.M. All authors have read and agreed to the published version of the manuscript.

Funding: This research received no external funding.

Institutional Review Board Statement: Not applicable.

Informed Consent Statement: Not applicable.

Data Availability Statement: No new data were created or analyzed in this study. Data sharing is not applicable to this article.

Conflicts of Interest: The authors declare no conflict of interest.

\section{References}

1. Chung, D.D.L. Processing-structure-property relationships of continuous carbon fiber polymer-matrix composites. Mater. Sci. Eng. R Rep. 2017, 113, 1-29. [CrossRef]

2. Koumoulos, E.P.; Trompeta, A.-F.; Santos, R.-M.; Martins, M.; dos Santos, C.M.; Iglesias, V.; Böhm, R.; Gong, G.; Chiminelli, A.; Verpoest, I.; et al. Research and Development in Carbon Fibers and Advanced High-Performance Composites Supply Chain in Europe: A Roadmap for Challenges and the Industrial Uptake. J. Compos. Sci. 2019, 3, 86. [CrossRef]

3. Galvez, P.; Quesada, A.; Martinez, M.A.; Abenojar, J.; Boada, M.J.L.; Diaz, V. Study of the behaviour of adhesive joints of steel with CFRP for its application in bus structures. Compos. Part B Eng. 2017, 129, 41-46. [CrossRef]

4. Xiong, Z.; Wei, W.; Liu, F.; Cui, C.; Li, L.; Zou, R.; Zeng, Y. Bond behaviour of recycled aggregate concrete with basalt fibrereinforced polymer bars. Compos. Struct. 2021, 256, 113078. [CrossRef]

5. Tang, Y.; Fang, S.; Chen, J.; Ma, L.; Li, L.; Wu, X. Axial compression behavior of recycled-aggregate-concrete-filled GFRP-steel composite tube columns. Eng. Struct. 2020, 216, 110676. [CrossRef]

6. Akbar, A.; Liew, K.M. Assessing recycling potential of carbon fiber reinforced plastic waste in production of eco-efficient cement-based materials. J. Clean. Prod. 2020, 274, 123001. [CrossRef]

7. Galvez, P.; Lopez de Armentia, S.; Abenojar, J.; Martinez, M.A. Effect of moisture and temperature on thermal and mechanical properties of structural polyurethane adhesive joints. Compos. Struct. 2020, 247, 112443. [CrossRef]

8. Rubino, F.; Nisticò, A.; Tucci, F.; Carlone, P. Marine application of fiber reinforced composites: A review. J. Mar. Sci. Eng. 2020, 8, 26. [CrossRef]

9. Sauer, M. Composites market report 2019-Market developments, trends, outlook and challenges. Carbon Compos. 2019, 1-10.

10. The World Bank GDP per Capita Growth (Annual \%). Available online: https://data.worldbank.org/indicator/NY.GDP.PCAP. KD.ZG?end=2020\&start=2000 (accessed on 28 September 2021).

11. Mazumdar, S.; Benevento, M.; Pichler, D.; Duenas, T.; Simonson, K. State of the Industry Report. American Composites Manufacturing Association, 2021; pp. 17-25. Available online: http://compositesmanufacturingmagazine.com/2021/02/2021 -state-of-the-industry-report/ (accessed on 28 September 2021).

12. Galvez, P.; Abenojar, J.; Martinez, M.A. Effect of moisture and temperature on the thermal and mechanical properties of a ductile epoxy adhesive for use in steel structures reinforced with CFRP. Compos. Part B Eng. 2019, 176, 107194. [CrossRef]

13. Smoleń, J.; Godzierz, M.; Olesik, P.; Pawlik, T.; Kozioł, M. Utilization of CFRP waste as a filler in polyester resin-based composites. J. Compos. Mater. 2021, 55, 2693-2701. [CrossRef]

14. Obande, W.; Brádaigh, C.M.Ó.; Ray, D. Continuous fibre-reinforced thermoplastic acrylic-matrix composites prepared by liquid resin infusion-A review. Compos. Part B Eng. 2021, 215, 108771. [CrossRef]

15. Ulus, H.; Kaybal, H.B.; Eskizeybek, V.; Avc1, A. Enhanced Salty Water Durability of Halloysite Nanotube Reinforced Epoxy/Basalt Fiber Hybrid Composites. Fibers Polym. 2019, 20, 2184-2199. [CrossRef]

16. Subagia, I.D.G.A.; Kim, Y.; Tijing, L.D.; Kim, C.S.; Shon, H.K. Effect of stacking sequence on the flexural properties of hybrid composites reinforced with carbon and basalt fibers. Compos. Part B Eng. 2014, 58, 251-258. [CrossRef]

17. Cheon, J.; Lee, M.; Kim, M. Study on the stab resistance mechanism and performance of the carbon, glass and aramid fiber reinforced polymer and hybrid composites. Compos. Struct. 2020, 234, 111690. [CrossRef]

18. Xiong, Z.; Wei, W.; He, S.; Liu, F.; Luo, H.; Li, L. Dynamic bond behaviour of fibre-wrapped basalt fibre-reinforced polymer bars embedded in sea sand and recycled aggregate concrete under high-strain rate pull-out tests. Constr. Build. Mater. 2021, 276, 122195. [CrossRef] 
19. Bahrami, M.; Abenojar, J.; Martínez, M.Á. Recent progress in hybrid biocomposites: Mechanical properties, water absorption, and flame retardancy. Materials 2020, 13, 5145. [CrossRef]

20. Gopalraj, S.K.; Kärki, T. A review on the recycling of waste carbon fibre/glass fibre-reinforced composites: Fibre recovery, properties and life-cycle analysis. SN Appl. Sci. 2020, 2, 433. [CrossRef]

21. Mishnaevsky, L. Sustainable end-of-life management of wind turbine blades: Overview of current and coming solutions. Materials 2021, 14, 1124. [CrossRef] [PubMed]

22. Boscán, I. La Industria Eólica Pide Que se Prohíba en EUROPA el Vertido de las Palas de los Aerogeneradores. Available online: https:/ / www.worldenergytrade.com/energias-alternativas/energia-eolica/la-industria-eolica-pide-que-se-prohibaen-europa-el-vertido-de-las-palas-de-los-aerogeneradores (accessed on 21 October 2021).

23. Jacob, A. Recycling threat to Europe's composites industry. Reinf. Plast. 2006, 50, 71-72. [CrossRef]

24. Marsh, G. Europe gets tough on end-of-life composites. Reinf. Plast. 2003, 47, 34-39. [CrossRef]

25. United Nations Framework Convention on Climate Change The Paris Agreement. Available online: https://unfccc.int/processand-meetings/the-paris-agreement/the-paris-agreement (accessed on 28 September 2021).

26. European Commission European Climate Law Climate Action. Available online: https://ec.europa.eu/clima/policies/euclimate-action/law_en (accessed on 28 September 2021).

27. European Parliament Directive 2000/53/EC of the European parliament and of the council of 18 September 2000 on end-of life vehicles. Off. J. Eur. Union 2000, 34-43.

28. Bledzki, A.K.; Seidlitz, H.; Goracy, K.; Urbaniak, M.; Rösch, J.J. Recycling of carbon fiber reinforced composite polymersReview-Part 1: Volume of production, recycling technologies, legislative aspects. Polymers 2021, 13, 300. [CrossRef] [PubMed]

29. Rajak, D.K.; Pagar, D.D.; Menezes, P.L.; Linul, E. Fiber-reinforced polymer composites: Manufacturing, properties, and applications. Polymers 2019, 11, 1667. [CrossRef] [PubMed]

30. Meng, F.; McKechnie, J.; Turner, T.; Wong, K.H.; Pickering, S.J. Environmental Aspects of Use of Recycled Carbon Fiber Composites in Automotive Applications. Environ. Sci. Technol. 2017, 51, 12727-12736. [CrossRef] [PubMed]

31. He, D.; Soo, V.K.; Kim, H.C.; Doolan, M. Life Cycle Primary Energy Demand and Greenhouse Gas Emission benefits of vehicle lightweighting with recycled carbon fibre. Procedia CIRP 2021, 98, 43-48. [CrossRef]

32. Tapper, R.J.; Longana, M.L.; Norton, A.; Potter, K.D.; Hamerton, I. An evaluation of life cycle assessment and its application to the closed-loop recycling of carbon fibre reinforced polymers. Compos. Part B Eng. 2020, 184, 107665. [CrossRef]

33. Kupski, J.; de Freitas, S.T. Design of adhesively bonded lap joints with laminated CFRP adherends: Review, challenges and new opportunities for aerospace structures. Compos. Struct. 2021, 268, 113923. [CrossRef]

34. Nikravesh, Y.; Muralidharan, K.; Frantziskonis, G. Techno-economic assessment and design optimization of compressed air energy storage using filament wound carbon fiber reinforced plastic pressure vessels. J. Energy Storage 2021, 40, 102754. [CrossRef]

35. Wan, Y.; Takahashi, J. Development of carbon fiber-reinforced thermoplastics for mass-produced automotive applications in japan. J. Compos. Sci. 2021, 5, 86. [CrossRef]

36. Abdallah, R.; Juaidi, A.; Sava, M.A.; Çamur, H.; Albatayneh, A. A Critical Review on Recycling Composite Waste Using Pyrolysis for Sustainable Development. Energies 2021, 14, 5748. [CrossRef]

37. Pickering, S.J.; Turner, T.A.; Meng, F.; Morris, C.N.; Heil, J.P.; Wong, K.H.; Melendi, S. Developments in the fluidised bed process for fibre recovery from thermoset composites. In Proceedings of the 2nd Annual Composites and Advanced Materials Expo, CAMX 2015, Dallas, TX, USA, 27-29 October 2015; pp. 2384-2394.

38. Pimenta, S.; Pinho, S.T.; Robinson, P.; Wong, K.H.; Pickering, S.J. Mechanical analysis and toughening mechanisms of a multiphase recycled CFRP. Compos. Sci. Technol. 2010, 70, 1713-1725. [CrossRef]

39. Zhu, J.H.; Chen, P.Y.; Su, M.N.; Pei, C.; Xing, F. Recycling of carbon fibre reinforced plastics by electrically driven heterogeneous catalytic degradation of epoxy resin. Green Chem. 2019, 21, 1635-1647. [CrossRef]

40. Kumar, S.; Krishnan, S. Recycling of carbon fiber with epoxy composites by chemical recycling for future perspective: A review. Chem. Pap. 2020, 74, 3785-3807. [CrossRef]

41. Verma, S.; Balasubramaniam, B.; Gupta, R.K. Recycling, reclamation and re-manufacturing of carbon fibres. Curr. Opin. Green Sustain. Chem. 2018, 13, 86-90. [CrossRef]

42. Pimenta, S.; Pinho, S.T. Recycling carbon fibre reinforced polymers for structural applications: Technology review and market outlook. Waste Manag. 2011, 31, 378-392. [CrossRef]

43. Bledzki, A.K.; Seidlitz, H.; Krenz, J.; Goracy, K.; Urbaniak, M.; Rösch, J.J. Recycling of carbon fiber reinforced composite polymers—review_part 2: Recovery and application of recycled carbon fibers. Polymers 2020, 12, 3003. [CrossRef] [PubMed]

44. Ma, C.; Sánchez-Rodríguez, D.; Kamo, T. Influence of thermal treatment on the properties of carbon fiber reinforced plastics under various conditions. Polym. Degrad. Stab. 2020, 178, 109199. [CrossRef]

45. Gopalraj, S.K.; Kärki, T. A study to investigate the mechanical properties of recycled carbon fibre/glass fibre-reinforced epoxy composites using a novel thermal recycling process. Processes 2020, 8, 954. [CrossRef]

46. Sun, H.; Guo, G.; Memon, S.A.; Xu, W.; Zhang, Q.; Zhu, J.H.; Xing, F. Recycling of carbon fibers from carbon fiber reinforced polymer using electrochemical method. Compos. Part A Appl. Sci. Manuf. 2015, 78, 10-17. [CrossRef]

47. Nahil, M.A.; Williams, P.T. Recycling of carbon fibre reinforced polymeric waste for the production of activated carbon fibres. $J$. Anal. Appl. Pyrolysis 2011, 91, 67-75. [CrossRef] 
48. Das, M.; Chacko, R.; Varughese, S. An Efficient Method of Recycling of CFRP Waste Using Peracetic Acid. ACS Sustain. Chem. Eng. 2018, 6, 1564-1571. [CrossRef]

49. Ma, Y.; Nutt, S. Chemical treatment for recycling of amine/epoxy composites at atmospheric pressure. Polym. Degrad. Stab. 2018, 153, 307-317. [CrossRef]

50. Meng, F.; McKechnie, J.; Turner, T.A.; Pickering, S.J. Energy and environmental assessment and reuse of fluidised bed recycled carbon fibres. Compos. Part A Appl. Sci. Manuf. 2017, 100, 206-214. [CrossRef]

51. Yazdanbakhsh, A.; Bank, L.C. A critical review of research on reuse of mechanically recycled FRP production and end-of-life waste for construction. Polymers 2014, 6, 1810-1826. [CrossRef]

52. Kouparitsas, C.E.; Kartalis, C.N.; Varelidis, P.C.; Tsenoglou, C.J.; Papaspyrides, C.D. Recycling of the fibrous fraction of reinforced thermoset composites. Polym. Compos. 2002, 23, 682-689. [CrossRef]

53. Ogi, K.; Nishikawa, T.; Okano, Y.; Taketa, I. Mechanical properties of ABS resin reinforced with recycled CFRP. Adv. Compos. Mater. Off. J. Japan Soc. Compos. Mater. 2007, 16, 181-194. [CrossRef]

54. Okayasu, M.; Yamazaki, T.; Ota, K.; Ogi, K.; Shiraishi, T. Mechanical properties and failure characteristics of a recycled CFRP under tensile and cyclic loading. Int. J. Fatigue 2013, 55, 257-267. [CrossRef]

55. Palmer, J.; Ghita, O.R.; Savage, L.; Evans, K.E. Successful closed-loop recycling of thermoset composites. Compos. Part A Appl. Sci. Manuf. 2009, 40, 490-498. [CrossRef]

56. Turner, T.A.; Pickering, S.J.; Warrior, N.A. Development of recycled carbon fibre moulding compounds-Preparation of waste composites. Compos. Part B Eng. 2011, 42, 517-525. [CrossRef]

57. Lee, H.; Ohsawa, I.; Takahashi, J. Effect of plasma surface treatment of recycled carbon fiber on carbon fiber-reinforced plastics (CFRP) interfacial properties. Appl. Surf. Sci. 2015, 328, 241-246. [CrossRef]

58. Roux, M.; Eguémann, N.; Dransfeld, C.; Thiébaud, F.; Perreux, D. Thermoplastic carbon fibre-reinforced polymer recycling with electrodynamical fragmentation: From cradle to cradle. J. Thermoplast. Compos. Mater. 2017, 30, 381-403. [CrossRef]

59. Yamamoto, T.; Makino, Y.; Uematsu, K. Improved mechanical properties of PMMA composites: Dispersion, diffusion and surface adhesion of recycled carbon fiber fillers from CFRP with adsorbed particulate PMMA. Adv. Powder Technol. 2017, 28, 2774-2778. [CrossRef]

60. Salas, A.; Medina, C.; Vial, J.T.; Flores, P.; Canales, C.; Tuninetti, V.; Jaramillo, A.F.; Meléndrez, M.F. Ultrafast carbon nanotubes growth on recycled carbon fibers and their evaluation on interfacial shear strength in reinforced composites. Sci. Rep. 2021, 11, 5000. [CrossRef]

61. Hirayama, D.; Saron, C.; Botelho, E.C.; Costa, M.L.; Junior, A.C.A. Polypropylene composites manufactured from recycled carbon fibers from aeronautic materials waste. Mater. Res. 2017, 20, 526-531. [CrossRef]

62. Chen, D. Development of Chemical Processes for the Recycling of Carbon Fiber/Epoxy Composites; UCLA: Los Angeles, CA, USA, 2020.

63. Pickering, S.J. Recycling technologies for thermoset composite materials-current status. Compos. Part A Appl. Sci. Manuf. 2006, 37, 1206-1215. [CrossRef]

64. Naqvi, S.R.; Prabhakara, H.M.; Bramer, E.A.; Dierkes, W.; Akkerman, R.; Brem, G. A critical review on recycling of end-of-life carbon fibre/glass fibre reinforced composites waste using pyrolysis towards a circular economy. Resour. Conserv. Recycl. 2018, 136, 118-129. [CrossRef]

65. Bradna, P.; Zima, J. Compositional analysis of epoxy matrices of carbon-fibre composites by pyrolysis-gas chromatography/mass spectrometry. J. Anal. Appl. Pyrolysis 1992, 24, 75-85. [CrossRef]

66. Meyer, L.O.; Schulte, K.; Grove-Nielsen, E. CFRP-recycling following a pyrolysis route: Process optimization and potentials. J. Compos. Mater. 2009, 43, 1121-1132. [CrossRef]

67. Greco, A.; Maffezzoli, A.; Buccoliero, G.; Caretto, F.; Cornacchia, G. Thermal and chemical treatments of recycled carbon fibres for improved adhesion to polymeric matrix. J. Compos. Mater. 2013, 47, 369-377. [CrossRef]

68. Stoeffler, K.; Andjelic, S.; Legros, N.; Roberge, J.; Schougaard, S.B. Polyphenylene sulfide (PPS) composites reinforced with recycled carbon fiber. Compos. Sci. Technol. 2013, 84, 65-71. [CrossRef]

69. López, F.A.; Rodríguez, O.; Alguacil, F.J.; García-Díaz, I.; Centeno, T.A.; García-Fierro, J.L.; González, C. Recovery of carbon fibres by the thermolysis and gasification of waste prepreg. J. Anal. Appl. Pyrolysis 2013, 104, 675-683. [CrossRef]

70. Kim, K.W.; Lee, H.M.; An, J.H.; Chung, D.C.; An, K.H.; Kim, B.J. Recycling and characterization of carbon fibers from carbon fiber reinforced epoxy matrix composites by a novel super-heated-steam method. J. Environ. Manag. 2017, 203, 872-879. [CrossRef] [PubMed]

71. Mazzocchetti, L.; Benelli, T.; D’Angelo, E.; Leonardi, C.; Zattini, G.; Giorgini, L. Validation of carbon fibers recycling by pyrogasification: The influence of oxidation conditions to obtain clean fibers and promote fiber/matrix adhesion in epoxy composites. Compos. Part A Appl. Sci. Manuf. 2018, 112, 504-514. [CrossRef]

72. Limburg, M.; Stockschläder, J.; Quicker, P. Thermal treatment of carbon fibre reinforced polymers (Part 1: Recycling). Waste Manag. Res. 2019, 37, 73-82. [CrossRef] [PubMed]

73. Wu, T.; Zhang, W.; Jin, X.; Liang, X.; Sui, G.; Yang, X. Efficient reclamation of carbon fibers from epoxy composite waste through catalytic pyrolysis in molten $\mathrm{ZnCl}_{2}$. RSC Adv. 2019, 9, 377-388. [CrossRef]

74. Abdou, T.R.; Junior, A.B.B.; Espinosa, D.C.R.; Tenório, J.A.S. Recycling of polymeric composites from industrial waste by pyrolysis: Deep evaluation for carbon fibers reuse. Waste Manag. 2021, 120, 1-9. [CrossRef] 
75. Lester, E.; Kingman, S.; Wong, K.H.; Rudd, C.; Pickering, S.; Hilal, N. Microwave heating as a means for carbon fibre recovery from polymer composites: A technical feasibility study. Mater. Res. Bull. 2004, 39, 1549-1556. [CrossRef]

76. Hao, S.; He, L.; Liu, J.; Liu, Y.; Rudd, C.; Liu, X. Recovery of carbon fibre from waste prepreg via microwave pyrolysis. Polymers 2021, 13, 1231. [CrossRef] [PubMed]

77. Jiang, J.; Deng, G.; Chen, X.; Gao, X.; Guo, Q.; Xu, C.; Zhou, L. On the successful chemical recycling of carbon fiber/epoxy resin composites under the mild condition. Compos. Sci. Technol. 2017, 151, 243-251. [CrossRef]

78. Borjan, D.; Knez, Ž.; Knez, M. Recycling of carbon fiber-reinforced composites- difficulties and future perspectives. Materials 2021, 14, 4191. [CrossRef] [PubMed]

79. Morales Ibarra, R.; Sasaki, M.; Goto, M.; Quitain, A.T.; García Montes, S.M.; Aguilar-Garib, J.A. Carbon fiber recovery using water and benzyl alcohol in subcritical and supercritical conditions for chemical recycling of thermoset composite materials. J. Mater. Cycles Waste Manag. 2014, 17, 369-379. [CrossRef]

80. Xing, M.; Li, Y.; Zhao, L.; Song, X.; Fu, Z.; Du, Y.; Huang, X. Swelling-enhanced catalytic degradation of brominated epoxy resin in waste printed circuit boards by subcritical acetic acid under mild conditions. Waste Manag. 2020, 102, 464-473. [CrossRef]

81. Piñero-Hernanz, R.; Dodds, C.; Hyde, J.; García-Serna, J.; Poliakoff, M.; Lester, E.; Cocero, M.J.; Kingman, S.; Pickering, S.; Wong, K.H. Chemical recycling of carbon fibre reinforced composites in nearcritical and supercritical water. Compos. Part A Appl. Sci. Manuf. 2008, 39, 454-461. [CrossRef]

82. Yamaguchi, A.; Hashimoto, T.; Kakichi, Y.; Urushisaki, M.; Sakaguchi, T.; Kawabe, K.; Kondo, K.; Iyo, H. Recyclable carbon fiber-reinforced plastics (CFRP) containing degradable acetal linkages: Synthesis, properties, and chemical recycling. J. Polym. Sci. Part A Polym. Chem. 2015, 53, 1052-1059. [CrossRef]

83. Wang, Y.; Cui, X.; Ge, H.; Yang, Y.; Wang, Y.; Zhang, C.; Li, J.; Deng, T.; Qin, Z.; Hou, X. Chemical Recycling of Carbon Fiber Reinforced Epoxy Resin Composites via Selective Cleavage of the Carbon-Nitrogen Bond. ACS Sustain. Chem. Eng. 2015, 3, 3332-3337. [CrossRef]

84. Yu, K.; Shi, Q.; Dunn, M.L.; Wang, T.; Qi, H.J. Carbon Fiber Reinforced Thermoset Composite with Near $100 \%$ Recyclability. Adv. Funct. Mater. 2016, 26, 6098-6106. [CrossRef]

85. Yan, H.; Lu, C.X.; Jing, D.Q.; Chang, C.B.; Liu, N.X.; Hou, X.L. Recycling of carbon fibers in epoxy resin composites using supercritical 1-propanol. Xinxing Tan Cailiao/New Carbon Mater. 2016, 31, 46-54. [CrossRef]

86. Henry, L.; Schneller, A.; Doerfler, J.; Mueller, W.M.; Aymonier, C.; Horn, S. Semi-continuous flow recycling method for carbon fibre reinforced thermoset polymers by near- and supercritical solvolysis. Polym. Degrad. Stab. 2016, 133, 264-274. [CrossRef]

87. Liu, T.; Zhang, M.; Guo, X.; Liu, C.; Liu, T.; Xin, J.; Zhang, J. Mild chemical recycling of aerospace fiber/epoxy composite wastes and utilization of the decomposed resin. Polym. Degrad. Stab. 2017, 139, 20-27. [CrossRef]

88. Oliveux, G.; Bailleul, J.L.; Gillet, A.; Mantaux, O.; Leeke, G.A. Recovery and reuse of discontinuous carbon fibres by solvolysis: Realignment and properties of remanufactured materials. Compos. Sci. Technol. 2016, 139, 99-108. [CrossRef]

89. Cheng, H.; Huang, H.; Zhang, J.; Jing, D. Degradation of carbon fiber-reinforced polymer using supercritical fluids. Fibers Polym. 2017, 18, 795-805. [CrossRef]

90. Okajima, I.; Watanabe, K.; Haramiishi, S.; Nakamura, M.; Shimamura, Y.; Sako, T. Recycling of carbon fiber reinforced plastic containing amine-cured epoxy resin using supercritical and subcritical fluids. J. Supercrit. Fluids 2016, 119, 44-51. [CrossRef]

91. Chaabani, C.; Weiss-Hortala, E.; Soudais, Y. Impact of Solvolysis Process on Both Depolymerization Kinetics of Nylon 6 and Recycling Carbon Fibers from Waste Composite. Waste Biomass Valorization 2017, 8, 2853-2865. [CrossRef]

92. Sokoli, H.U.; Beauson, J.; Simonsen, M.E.; Fraisse, A.; Brøndsted, P.; Søgaard, E.G. Optimized process for recovery of glass- and carbon fibers with retained mechanical properties by means of near- and supercritical fluids. J. Supercrit. Fluids 2017, 124, 80-89. [CrossRef]

93. Okajima, I.; Sako, T. Recycling fiber-reinforced plastic using supercritical acetone. Polym. Degrad. Stab. 2019, 163, 1-6. [CrossRef]

94. Lee, M.; Kim, D.H.; Park, J.J.; You, N.H.; Goh, M. Fast chemical recycling of carbon fiber reinforced plastic at ambient pressure using an aqueous solvent accelerated by a surfactant. Waste Manag. 2020, 118, 190-196. [CrossRef]

95. Khalil, Y.F. Sustainability assessment of solvolysis using supercritical fluids for carbon fiber reinforced polymers waste management. Sustain. Prod. Consum. 2019, 17, 74-84. [CrossRef]

96. Van de Werken, N.; Reese, M.S.; Taha, M.R.; Tehrani, M. Investigating the effects of fiber surface treatment and alignment on mechanical properties of recycled carbon fiber composites. Compos. Part A Appl. Sci. Manuf. 2019, 119, 38-47. [CrossRef]

97. Sukanto, H.; Raharjo, W.W.; Ariawan, D.; Triyono, J. Carbon fibers recovery from CFRP recycling process and their usage: A review. IOP Conf. Ser. Mater. Sci. Eng. 2021, 1034, 012087. [CrossRef]

98. Mantelli, A.; Romani, A.; Suriano, R.; Diani, M.; Colledani, M.; Sarlin, E.; Turri, S.; Levi, M. UV-assisted 3D printing of polymer composites from thermally and mechanically recycled carbon fibers. Polymers 2021, 13, 726. [CrossRef] [PubMed]

99. Takahashi, J.; Matsutsuka, N.; Okazumi, T.; Uzawa, K.; Ohsawa, I.; Yamaguchi, K.; Kitano, A. Mechanical properties of recycled CFRP by injection molding method. In Proceedings of the ICCM International Conferences on Composite Materials, Kyoto, Japan, 8-13 July 2007.

100. Wong, K.H.; Mohammed, D.S.; Pickering, S.J.; Brooks, R. Effect of coupling agents on reinforcing potential of recycled carbon fibre for polypropylene composite. Compos. Sci. Technol. 2012, 72, 835-844. [CrossRef]

101. Akonda, M.H.; Lawrence, C.A.; Weager, B.M. Recycled carbon fibre-reinforced polypropylene thermoplastic composites. Compos. Part A Appl. Sci. Manuf. 2012, 43, 79-86. [CrossRef] 
102. Giorgini, L.; Benelli, T.; Mazzocchetti, L.; Leonardi, C.; Zattini, G.; Minak, G.; Dolcini, E.; Cavazzoni, M.; Montanari, I.; Tosi, C. Recovery of carbon fibers from cured and uncured carbon fiber reinforced composites wastes and their use as feedstock for a new composite production. Polym. Compos. 2015, 36, 1084-1095. [CrossRef]

103. Onwudili, J.A.; Miskolczi, N.; Nagy, T.; Lipóczi, G. Recovery of glass fibre and carbon fibres from reinforced thermosets by batch pyrolysis and investigation of fibre re-using as reinforcement in LDPE matrix. Compos. Part B Eng. 2016, 91, 154-161. [CrossRef]

104. Andrzejewski, J.; Misra, M.; Mohanty, A.K. Polycarbonate biocomposites reinforced with a hybrid filler system of recycled carbon fiber and biocarbon: Preparation and thermomechanical characterization. J. Appl. Polym. Sci. 2018, 135, 46449. [CrossRef]

105. Matrenichev, V.; Belone, M.C.L.; Palola, S.; Laurikainen, P.; Sarlin, E. Resizing approach to increase the viability of recycled fibre-reinforced composites. Materials 2020, 13, 5773. [CrossRef]

106. Huang, H.; Liu, W.; Liu, Z. An additive manufacturing-based approach for carbon fiber reinforced polymer recycling. CIRP Ann. 2020, 69, 33-36. [CrossRef]

107. Yao, S.S.; Jin, F.L.; Rhee, K.Y.; Hui, D.; Park, S.J. Recent advances in carbon-fiber-reinforced thermoplastic composites: A review. Compos. Part B Eng. 2018, 142, 241-250. [CrossRef] 